\title{
international society for twin studies
}

\section{FIFTH INTERNATIONAL CONGRESS ON TWIN STUDIES}

1.1. Time, Place, and Connected Meeting. The Fifth International Congress on Twin Studies will take place in Amsterdam on 15-19 September 1986, a Monday through a Friday.

The following week (Monday 22.Friday 26), the Seventh International Congress of Human Genetics is scheduled to take place in West Berlin. The two cities are well connected and the participants to the Twin Congress who should be interested to proceed on to Berlin can leave Amsterdam on either Friday night or Monday morning ( $1 \mathrm{hr}$ flight).

1.2. Site. The Congress will take place at the Grand Hotel Krasnapolsky, which is very centrally located, facing the Royal Palace, and represents the heart of oldfashioned Amsterdam, with over one hundred years of tradition. The hotel incorporates one of the finest Convention Centers in Amsterdam, which is just now being renovated.

1.3. Accommodation. There will be rooms available at the Krasnapolsky at a rate of approximately US $\$ 70.00$ for a single room with bath (about $\$ 90.00$ for a double, including full buffet breakfast, service and taxes. There will also be rooms available in nearby hotels at even much cheaper rates (down to some US $\$ 25.00$ a day). Student quarter arrangements may also be provided.

1.4. Registration Fees. Registration fees have been set as follows: Before 28 Feb 86 :

$\begin{array}{ll}\text { Regular, } & \text { Dff } 500.00 \\ \text { Accompanying person, } & \text { Dff } 200.00\end{array}$

After 28 Feb 86 :

Regular,

Df। 600.00

Accompanying person,

Dfl 250.00

(Approximate exchange rate: US $\$ 1.00=\mathrm{Dff} 3.50$ )

1.5. Local Arrangements. The Congress will be hosted by

Professor Aldur W. Eriksson

Director of the Institute of Human Genetics

Faculty of Medicine, Free University of Amsterdam

who will act as Chairman of the Organizing Committee. Professor Eriksson will be assisted by some of his Institute's associates, by the Twins Association of Holland, and by the ISTS Secretary General.
1.6. Program. The congress will start on Monday 15, with registration in the afternoon and get-together in the night, and end on Friday 19 at lunch time, thus leaving three more nights for social events and four mornings and three afternoons for the scientific program. The latter will essentially follow the structure successfully adopted at previous congresses, with plenary sessions in the morning and concurrent sessions in the afternoon.

There should be 8 Symposia, each with four $20^{\prime}$ presentations, 3 Workshops, and some 12-15 Concurrent Sessions of contributed papers. The following and related topics shall be dealt with:

- Biology of Twinning: incidence, etiology, embryology, teratology

- Multiple Pregnancy: early diagnostic, treatment, labor, perinatology

- Twins, Family and Society: aspects and problems of the twin condition at the individual, family, and social level

- Methodology of Twin Studies

- Psychology of Twinning

- Behavior Genetics

- Psychiatric Genetics

- Developmental Studies: physical and mental growth of twins developmental genetics

- Chronogenetics

- Aging

- Cancer

- Diabetes

- Obesity

- Coronary Heart Disease

- Smoking, Alcohol, Substance Exposure, Drug Abuse etc.

The scientific program will result from the joint effort of ISTS Board members coordinated by the Secretary General and under the responsibility of the current President, Professor Walter $E$. Nance (Dept. Human Genetics, Medical College of Virginia, Richmond). Suggestions or comments are cordially invited. 


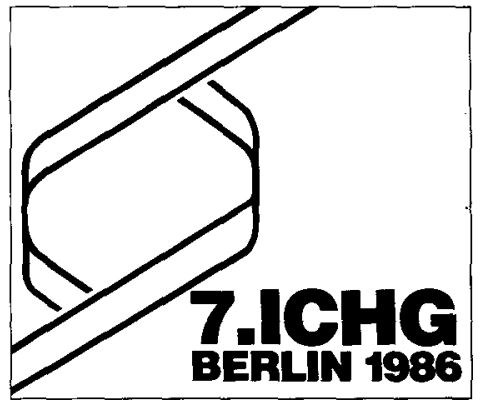

\section{Preliminary Topics}

Lectures, Symposia, Workshops

Organization of the human genome

Molecular basis of human disease

Approaches to gene-replacement therapy

Oncogenes

Inborn errors of metabolism

DNA repair defects

Pharmacogenetics - ecogenetics

Clinical cytogenetics

Etiology of fetal wastage

Genetics of common disease

Psychobiological genetics

Current status of prenatal diagnosis

Population screening

Population aspects of hereditary diseases

Genetics of embryonic development

Sex differentiation

Mitochondrial genetics

Gene amplification

Linkage developments

Genetic counseling using DNA polymorphisms

Teaching of medical genetics and training of medical geneticists

Ethical issues of modern human genetics

Satellite meetings have so far been planned in the following fields:

Cancer cytogenetics

Computerized chromosome evaluation

Pharmacogenetics

Patho-anatomical syndrome diagnosis

Alpha-fetoprotein diagnosis

Population monitoring

\section{Exhibitions}

There will be an industrial exhibition of all kinds of equipment as well as an exhibition of research supplies, books, and journals. In addition a special exhibition on "Hereditary diseases and malformations in art" is planned. In case you are aware of pictures, sculptures etc. showing such anomalies, please contact Dr. J. Kunze (Congress Secretariat).

\section{$7^{\text {th }}$ International Congress of Human Genetics}

\section{General Information}

\section{Congress venue}

The meeting will take place at the International Congress Center Berlin (West), Messedamm 22, D-1000 Berlin 19, which can be reached by subway, city railroad and bus etc.

\section{Travel and accomodation}

Berlin can be reached by air, road, and rail. The city offers a large number of rooms of all categories, inci. a limited supply for students in youth hotels.

\section{Social and cultural activities}

Berlin is known for its rich and varied cultural scene. Participants may choose between theatre and concert programs, between guided tours to the historic sites of the city or its famous museums.

A program of social events will be offered to all participants and the accompanying persons.

\section{Second Announcement}

The second circular incl. all registration forms will be distributed in fall / winter 1985. It will be sent to those having preregistered on the attached card by DERCONGRESS.

Correspondence concerning the scientific program should be addressed to the

\section{Congress Secretariat}

7 th International Congress of Human Genetics Institute of Human Genetics

Heubnerweg 6

D-1000 Berlin 19

Tel.: (030) 3203377

Correspondence concerning congress registration, hotel accomodation, guided tours, and travel arrangements should be addressed to the

Congress Bureau

DER-CONGRESS

Congress Organization

Augsburger Strasse 27

D-1000 Berlin 30

Tel.: (030) 246011

Telex: 184124 derc $d$ 


\section{INTERNATIONAL WORKSHOP

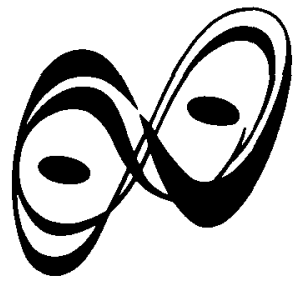

SEPTEMBER 25-27 1985

On the initiative of the International Society for Twin Studies, an international Workshop on Twin Pregnancies is held every year. The Conference of 1985 will be arranged on September 25-27 in TOULOUSE, in the south of France, by $\mathrm{H}$. GRANDJEAN (Toulouse) and E. PAPIERNIK (Paris). The conference sessions will be held in the center of the town (Salle du Senechal) where several types of accommodations are available.

One part of the Conference will be devoted to the registers of twin pregnancies. The other part of the Conference will deal with all the problems related to management and outcome of twin pregnancy. You are cordially invited to participate and to submit free communications on subjects concerning twin pregnancy. The organising comittee will regroup the communications according main topics and reserves the right to refer submitted papers to a poster session in order to secure sufficient time for discussions during the proceedings. Time alloted for the presentation of each paper is $15 \mathrm{~min}$. followed by $10 \mathrm{~min}$. discussion.

People intending to present a paper are requested to give the title before june 15 th and to send an abstract before july the 31 th (l page 21 x 29,7 cm) to Helène GRANDJEAN. Hotel reservation form is attached.

\section{REGISTRATION FORM}

Surname: First name:

Mailing address:

I intend to participate to the workshop $\square$

to present a paper

title:

Please return to Hélène GRANJEAN

INSERM U 168 - Hôpitđl LA GRAVE 31052 TOULOUSE Cedex

before JUNE 15th 